\title{
Evidence of false-positive results in a commercially available rotavirus assay in the vaccine era, Australia, 2011 to 2012
}

S Ye ${ }^{1,2}$, S Roczo-Farkas3, D M Whiley ${ }^{1,2}$, S B Lambert (sblambert@uq.edu.au) ${ }^{1,4}$, J Robson ${ }^{5}$, C Heney $^{2}$, G Nimmo $^{2}$, K Grimwood $^{1}$,

T P Sloots ${ }^{1,2}$, C D Kirkwood ${ }^{3,6}$

1. Queensland Paediatric Infectious Diseases Laboratory, Queensland Children's Medical Research Institute, The University of Queensland, Brisbane, Queensland, Australia

2. Microbiology Division, Pathology Queensland Central Laboratory, Herston, Queensland, Australia

3. Enteric Virus Research Group, Murdoch Childrens Research Institute, Parkville, Victoria, Australia

4. Queensland Health Immunisation Program, Queensland Health, Brisbane, Australia

5. Sullivan Nicolaides Pathology, Brisbane, Australia

6. Department of Microbiology, La Trobe University, Bundoora, Victoria, Australia

Ye S, Roczo-Farkas S, Whiley DM, Lambert SB, Robson J, Heney C, Nimmo G, Grimwood K, Sloots TP, Kirkwood CD. Evidence of false-positive results in a commercially available rotavirus assay in the vaccine era, Australia, 2011 to 2012 . Euro Surveill. 2013;18(21): pii=20483. Available online: http://www.

commercially available rotavirus assay in the vaccine era,
eurosurveillance.org/ViewArticle.aspx?Articleld $=2048$

Article submitted on 16 April 2013 / published on 23 May 2013

Concerns were raised about specificity of the VIKIA Rota-Adeno immunochromatographic kit. Only 28-37\% of samples positive with the VIKIA kit could be confirmed using two real-time RT-PCR assays and three ELISA kits. On re-analysis of a subset of the positive samples, $86 \%$ remained positive with the VIKIA kit, however, $90 \%$ remained negative in the other assays. In a highly vaccinated population we found a high number of false-positive rotavirus tests with a widelyused commercial kit.

We recently became concerned about the specificity of the VIKIA Rota-Adeno assay (bioMérieux, France) following an unexplained increase in positive results and feedback from clinicians.

Accurate detection of rotavirus is essential for prevention and control of rotavirus outbreaks and disease monitoring. There are two common methods used for routine diagnosis: immunochromatographic (ICT) assays and enzyme-linked immunosorbent assays (ELISA). ICT assays are relatively inexpensive, easy to use, rapid (results within $20 \mathrm{~min}$ ) and with reportedly good sensitivity (96.6\%) and specificity (92.9\%) [1]. Many diagnostic laboratories in Australia use the VIKIA Rota-Adeno assay for detection of rotavirus in faecal specimens.

We therefore re-examined samples initially testing positive in the VIKIA Rota-Adeno ICT with other commercially available ELISA rotavirus assays and, for a subset of specimens, by RT-PCR.

\section{Methods}

Ethics approval for this study was provided by the Children's Health Queensland Human Research Ethics Committee.

\section{Clinical specimens}

We obtained a convenience sample set of 133 faecal specimens submitted for diagnostic rotavirus testing and collected between July 2011 and August 2012 from patients with symptoms of acute gastroenteritis. Specimens were from two laboratories in Queensland ( $n=113$ : Pathology Queensland, a publically funded laboratory, and Sullivan Nicolaides Pathology, a private laboratory) and from a private laboratory network in Victoria ( $n=20$ : Melbourne Pathology). The latter were submitted to the National Rotavirus Reference Centre (NRRC) in Melbourne, Victoria, for genotyping. All samples had been tested initially for rotavirus using the VIKIA ICT method according to the manufacturer's instructions (Queensland: 81 positive, 32 negative; Victoria: 20 positive).

Real-time RT-PCR, Queensland samples only All 113 Queensland specimens were tested initially in Queensland employing two real-time RT-PCR assays, using primers and TaqMan probe sequences described previously:

NVP3-PCR (NVP3-F1 ACCATCTACACATGACCCTC, NVP3-F2 ACCATCTTCACGTAACCCTC, $\mathrm{NVP}_{3}-\mathrm{R}$ GGTCACATAACGCCC, NVP3 probe ATGAGCACAATAGTTAAAAGCTAACACTGTCAA) [2,3], JVK-PCR (JVK-F CAGTGGTTGATGCTCAAGATGGA, JVK-R TCATTGTAATCATATTGAATACCCA, JVK probe ACAACTGCAGCTTCAAAAGAAGWGT) [4].

RNA extraction was performed by homogenising ca. 25 $\mu \mathrm{l}$ of stool specimen with $225 \mu$ l of phosphate buffered saline to provide a concentration of ca. $10 \%$. Then 200 $\mu \mathrm{l}$ of this suspension were extracted into a volume of $50 \mu \mathrm{l}$ using the Roche High Pure Nucleic Acid extraction kit as per kit instructions (Roche Diagnostics, Australia). As described previously, specimens were 
TABLE 1

Comparison of original VIKIA test results and repeat VIKIA test results for specimens with sufficient volume for re-testing, Queensland, July 2011-August 2012 (n=61)

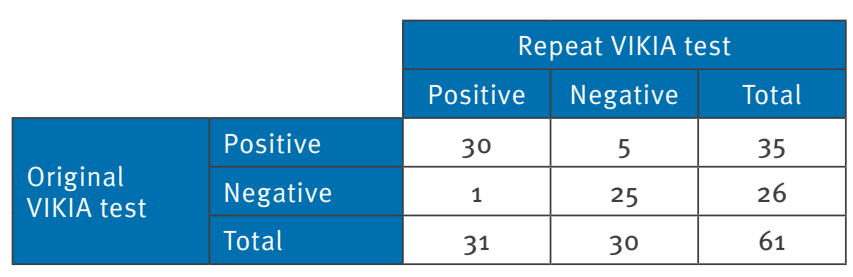

spiked before extraction with $5 \mu$ of equine herpes virus as an extraction and inhibition control [5].

All real-time RT-PCR reactions were performed using a Qiagen one-step RT-PCR kit. Each reaction mix contained in a total volume of $25.0 \mu \mathrm{l}$ in RNase-free water: $0.4 \mu \mathrm{M}$ of forward and reverse primers, $0.16 \mu \mathrm{M}$ of Taqman probe, $1.0 \mu \mathrm{l}$ of Qiagen one-step RT-PCR dNTP mix, 5.0 $\mu \mathrm{l}$ of Qiagen one-step RT-PCR buffer (5x), 1.0 $\mu \mathrm{l}$ of RT-enzyme and $2.0 \mu \mathrm{l}$ of RNA extract or control. Cycling was performed on a Rotor-Gene instrument (Qiagen, Australia) or Applied Biosystems 7500 realtime PCR system (Life Technologies, United States) with the following cycling conditions: initial hold steps at $50{ }^{\circ} \mathrm{C}$ for $20 \mathrm{~min}$ and $95{ }^{\circ} \mathrm{C}$ for $15 \mathrm{~min}$, followed by $45 \mathrm{cycles}$ at $95^{\circ} \mathrm{C}$ for $15 \mathrm{sec}$ and $60^{\circ} \mathrm{C}$ for $30 \mathrm{sec}$, with fluorescence signal read on green at $60^{\circ} \mathrm{C}$.

\section{ELISA testing}

There were 103 samples available at the NRRC for further testing: 83 from Queensland (51 VIKIA-positive, 32 VIKIA-negative specimens) and 20 specimens from Victoria. Thirty VIKIA-positive specimens from Queensland were not sent to the NRRC due to insufficient sample volume. Available specimens were retested using three commercial rotavirus ELISA assays: ProSpecT (Oxoid, United Kingdom), Premier Rotaclone (Bioline, United Kingdom) and Ridascreen (R-Biopharm AG, Germany). All three methods were performed as per the manufacturer's instructions.

\section{VIKIA retesting}

To confirm initial VIKIA assay results, Queensland specimens with sufficient remaining sample (positive: $n=35$; negative: $n=26$ ) after PCR and ELISA testing, were retested using the VIKIA assay.

\section{In-house VP6 RT-PCR}

At NRRC, any samples that gave a discordant result for the ELISA methods or appeared to be falsely positive in the VIKIA assay $(n=55)$, were further tested using a rotavirus VP6-specific RT-PCR with primers ROT3 AAAGATGCTAGGGACAAAATTG and ROT5 TTCAGATTGTGGAGCTATTCCA $[6,7]$.

\section{Results}

\section{Samples from Queensland retested \\ in a second VIKIA assay}

Of the 81 VIKIA-positive and 32 VIKIA-negative Queensland samples, there was sufficient remaining specimen for VIKIA retesting on 35 and 26 specimens, respectively. Thirty of 35 initially VIKIA-positive and one of 26 initially VIKIA-negative Queensland specimens were positive on retesting (Table 1).

Twenty-seven of the 30 VIKIA twice-positive samples were negative in every other assay applied (Table 2). Of the 10 VIKIA retest-positive specimens with sufficient sample volume available for testing at the NRRC, seven were negative by all three ELISA assays (Table

\section{TABLE 2}

Test results for specimens with sufficient volume for VIKIA re-testing, in PCR and ELISA assays, Queensland, July 2011-August $2012(\mathrm{n}=61)$

\begin{tabular}{|c|c|c|c|c|c|c|c|c|c|c|c|}
\hline & & \multicolumn{3}{|c|}{$\begin{array}{l}\text { Queensland PCR } \\
\text { (NVP3 } 3 \text { and JVK) }\end{array}$} & \multicolumn{3}{|c|}{$\begin{array}{l}\text { Melbourne ELISA assays } \\
\text { (ProSpect, Rotaclone, } \\
\text { Ridascreen) }\end{array}$} & \multicolumn{4}{|c|}{ Victorian PCR } \\
\hline & & Positive & Negative & Total & Positive & Negative & Total & Positive & Negative & NP & Total \\
\hline \multirow{3}{*}{$\begin{array}{l}\text { Repeat } \\
\text { VIKIA } \\
\text { test }\end{array}$} & Positive & 2 & 29 & 31 & $3^{\mathrm{a}}$ & 7 & 10 & 0 & 7 & 3 & 10 \\
\hline & Negative & $1^{\mathrm{b}}$ & 29 & 30 & 0 & 25 & 25 & 0 & 0 & 25 & 25 \\
\hline & Total & 3 & 58 & 61 & 3 & 32 & 35 & 0 & 7 & 28 & 35 \\
\hline
\end{tabular}

a Two specimens positive in all three assays, one specimen positive in Rotaclone only.

b One sample positive in single RT-PCR assay, NVP3, only (cycle threshold: ca. 37 cycles). 
TABLE 3

Restesting with different diagnostic assays of faecal specimens positive in the VIKIA assay, Queensland and Victoria, July 2011-August $2012(\mathrm{n}=133)$

\begin{tabular}{|c|c|c|c|c|c|c|c|c|}
\hline \multirow[t]{2}{*}{ VIKIA initiala } & \multicolumn{2}{|c|}{ Queensland PCR assays } & \multicolumn{3}{|c|}{ ELISA assays } & \multirow{2}{*}{ VIKIA retest ${ }^{b}$} & \multirow{2}{*}{$\begin{array}{l}\text { Melbourne } \\
\text { PCR assay } \\
\text { VP6-PCRe }\end{array}$} & \multirow{2}{*}{ Number } \\
\hline & $N P_{3}-P_{C} R^{c}$ & JVK-PCR & ProSpect ${ }^{d}$ & Rotaclone $^{d}$ & Ridascreen $^{d}$ & & & \\
\hline \multicolumn{8}{|c|}{ Queensland specimens from Pathology Queensland and Sullivan Nicolaides Pathology, original diagnostic test: VIKIA } & 113 \\
\hline \multicolumn{8}{|c|}{ Queensland specimens with insufficient material for sending to the NRRC } & 30 \\
\hline POS & POS & POS & NP & NP & NP & NP & NP & 2 \\
\hline POS & NEG & NEG & NP & NP & NP & POS & NP & 21 \\
\hline POS & NEG & NEG & NP & NP & NP & NEG & NP & 5 \\
\hline POS & NEG & NEG & NP & NP & NP & NP & NP & 2 \\
\hline \multicolumn{8}{|c|}{ Queensland specimens with sufficient material for sending to the NRRC } & 83 \\
\hline POS & POS & POS & POS & POS & POS & POS & NP & 2 \\
\hline POS & POS & POS & POS & POS & POS & NP & NP & 14 \\
\hline POS & POS & POS & POS & POS & NEG & NP & POS & 1 \\
\hline POS & POS & POS & NEG & POS & POS & NP & NEG & 1 \\
\hline POS & NEG & POS & NEG & NEG & NEG & NP & NEG & 1 \\
\hline POS & NEG & POS & NEG & NEG & POS & NP & NEG & 1 \\
\hline POS & POS & NEG & NEG & NEG & NEG & NP & POS & 1 \\
\hline POS & NEG & NEG & NEG & POS & NEG & POS & NEG & 1 \\
\hline POS & NEG & NEG & NEG & NEG & NEG & POS & NEG & 6 \\
\hline POS & NEG & NEG & NEG & NEG & NEG & $N P$ & NEG & 23 \\
\hline NEG & POS & NEG & NEG & NEG & NEG & NEG & NP & 1 \\
\hline NEG & NEG & NEG & NEG & NEG & NEG & POS & NP & 1 \\
\hline NEG & NEG & NEG & NEG & NEG & NEG & NP & NP & 6 \\
\hline NEG & NEG & NEG & NEG & NEG & NEG & NEG & NP & 24 \\
\hline \multicolumn{8}{|c|}{ Specimens from Victoria provided to the NRRC for genotyping, original diagnostic test: VIKIA } & 20 \\
\hline POS & NP & NP & NEG & NEG & NEG & NP & NEG & 13 \\
\hline POS & NP & NP & NEG & POS & NEG & NP & NEG & 1 \\
\hline POS & NP & NP & POS & POS & POS & NP & POS & 6 \\
\hline
\end{tabular}

ELISA: enzyme-linked immunosorbent assay; NEG: specimens negative in this assay; NP: test not performed on this specimen; NRRC: National Rotavirus Reference Centre; PCR: polymerase chain reaction; POS: specimens positive in this assay.

a Initial diagnostic test.

b VIKIA retest performed on specimens with remaining adequate volume after PCR/ELISA testing.

Queensland PCR, not performed on Victorian samples.

d ELISA tests performed at the National Rotavirus Reference Centre, Melbourne.

e PCR performed at the National Rotavirus Reference Centre, Melbourne, on specimens discordant for any of the ELISA tests.

2). The initially negative, but retest-positive specimen was negative by the NVP3 and JVK PCR assays, and all three ELISA tests.

Other specimens from Queensland and Victoria available for testing in other assays There were further specimens from Queensland $(n=52$; 46 positive, six negative) and Victoria $(n=20$; all positive) which were not retested using the VIKIA assay, but for which PCR and ELISA results were available.
Of 20 VIKIA-positive specimens from Victoria, 13 were negative in all three ELISA assays and the VP6 PCR assay (Table 3 ). The six negative specimens from Queensland were negative in both $\mathrm{NVP}_{3}$ and JVK PCR assays, and all three ELISA assays. Four of the 46 positive specimens did not have sufficient specimen volume remaining for ELISA testing; two of these positive in both the NVP 3 and JVK assays, and two negative in both (Table 3). Of the remaining 42 specimens, 14 were positive in both Queensland PCR assays and all three ELISA assays, and 23 were negative in each of these 
assays as well as the VP6 PCR assay. The remaining five specimens provided mixed results.

\section{Discussion}

The results of our study highlight the need to review the validity of diagnostic assays when disease incidence changes unexpectedly. Australia implemented a nationwide rotavirus vaccination programme in July 2007, and since that time notifications of laboratoryconfirmed rotavirus infections and hospitalisations have fallen quickly in targeted and older age-groups [8-10]. Anecdotal feedback from clinicians and an unexplained increase in disease notifications prompted this investigation, which has identified a problem with false positivity in an ICT assay used widely in Australia and elsewhere.

Even though ours is a convenience sample, the results point towards inability to confirm by a variety of PCR and ELISA methods a substantial proportion of specimens twice positive using the VIKIA kit. These findings were reinforced by specimens from Queensland and Victoria which were tested only once using the VIKIA assay. As a sensitivity analysis, if we assume the remaining 46 initially VIKIA positive specimens with insufficient volume for retesting had all retested negative, there would still remain 27 of 81 Queensland specimens that were twice positive by the VIKIA assay, but were negative in two PCR assays $(n=21)$ or three PCR assays and three ELISA assays $(n=6)($ Table 3$)$.

Given the consistency of other methods it is unlikely that the ICT assay is detecting true positive results. Notably, our data suggest that between one and two thirds of VIKIA-positive samples may be actually falsepositive results. Furthermore, of initially positive samples from Queensland with sufficient volume for repeat testing using the VIKIA kit, $86 \%$ remained positive on retest, with only three of these 30 specimens positive in one or more other assay, by PCR or ELISA. Given the consistency of the VIKIA retest values and our PCR and ELISA assay findings, conducted at different times in different locations, with all assays performed according to the manufacturer's instructions, we do not believe specimen degradation or test conditions are a logical or sustainable explanation for the apparent specificity issue. There were six Queensland specimens for which the VIKIA retest value differed from the original result, with five of these initially positive and negative in the repeat test. Possible reasons for these discrepancies include sample stability, human error in result interpretation, and specimens with low virus load.

The VIKIA ICT kit insert states that the method has $100 \%$ sensitivity and $100 \%$ specificity for rotavirus detection, based on testing of 103 positive and 290 negative stools [11]. In a prospective study of 57 samples from children younger than 36 months in Lyon in childcare centres during 2004-05, the reported sensitivity and specificity of this kit, compared to a PCRbased method, was $96.6 \%$ and $96.4 \%$ respectively
(PPV: 96.5\%, NPV: 92.9\%) [1]. Similar high specificity (100\%) was reported by Bon et al. in 2006 [12]. Given this, it is difficult to know if our findings are due to recent changes in the assay or to specificity problems exposed by reduced disease incidence in a high vaccine coverage setting. We are therefore investigating further the specificity of this and other assays in a prospective study.

\section{Conclusion}

We have shown a suboptimal test specificity using a commercially available rotavirus ICT assay. Assayspecific issues should be considered in the event of unexplained increases of rotavirus disease in the vaccine era.

Conflict of interest

None declared.

Authors' contributions

All authors collaborated on the design and conduct of the study. JR, CH, GN provided specimens. SY, SR-F performed PCR and ELISA testing on specimens. SY, DMW, SBL, KG analysed the data. SY wrote the first draft of the paper. All authors contributed to critical revision of the manuscript and have seen and approved the final version of the manuscript. 


\section{References}

1. de Rougemont A, Kaplon J, Billaud G, Lina B, Pinchinat S, Derrough T, et al. [Sensitivity and specificity of the VIKIA Rota-Adeno immuno-chromatographic test (bioMérieux) and the ELISA IDEIA Rotavirus kit (Dako) compared to genotyping]. Pathol Biol (Paris). 2009;57(1):86-9. French. http://dx.doi. org/10.1016/j.patbio.2008.08.004 PMid:18838230

2. Pang $X$, Cao $M$, Zhang $M$, Lee $B$. Increased sensitivity for various rotavirus genotypes in stool specimens by amending three mismatched nucleotides in the forward primer of a realtime RT-PCR assay. J Virol Methods. 2011;172(1-2):85-7. http:// dx.doi.org/10.1016/j.jviromet.2010.12.013 PMid:21185331

3. Pang XL, Lee B, Boroumand N, Leblanc B, Preiksaitis JK, Yu Ip CC. Increased detection of rotavirus using a real time reverse transcription-polymerase chain reaction (RT-PCR) assay in stool specimens from children with diarrhea. J Med Virol. 2004;72(3):496-501. http://dx.doi.org/10.1002/jmv.20009 PMid:14748075

4. Jothikumar N, Kang G, Hill VR. Broadly reactive TaqMan assay for real-time RT-PCR detection of rotavirus in clinical and environmental samples. J Virol Methods. 2009;155(2):12631. http://dx.doi.org/10.1016/j.jviromet.2008.09.025 PMid:18951923

5. Bialasiewicz S, Whiley DM, Bautista C, Barker K, Aitken S, Gordon R, et al. A novel gel-based method for self-collection and ambient temperature postal transport of urine for PCR detection of Chlamydia trachomatis. Sex Transm Infect. 2009;85(2):102-5. http://dx.doi.org/10.1136/sti.2008.032607 PMid: 19004866

6. Elschner M, Prudlo J, Hotzel H, Otto P, Sachse K. Nested reverse transcriptase-polymerase chain reaction for the detection of group A rotaviruses. J Vet Med B Infect Dis Vet Public Health. 2002;49(2):77-81. http://dx.doi.org/10.1046/ j.1439-0450.2002.00510.x PMid:12002423

7. Donato CM, Ch'ng LS, Boniface KF, Crawford NW, Buttery JP, Lyon M, et al. Identification of strains of RotaTeq rotavirus vaccine in infants with gastroenteritis following routine vaccination. J Infect Dis. 2012;206(3):377-83. http://dx.doi. org/10.1093/infdis/jis361 PMid:22615314

8. Lambert SB, Faux CE, Hall L, Birrell FA, Peterson KV, Selvey $\mathrm{CE}$, et al. Early evidence for direct and indirect effects of the infant rotavirus vaccine program in Queensland. Med J Aust. 2009;191(3):157-60. PMid:19645646

9. Field EJ, Vally H, Grimwood K, Lambert SB. Pentavalent rotavirus vaccine and prevention of gastroenteritis

hospitalizations in Australia. Pediatrics. 2010;126(3):e506-12. http://dx.doi.org/10.1542/peds.2010-0443 PMid:20732946

10. Buttery JP, Lambert SB, Grimwood K, Nissen MD, Field EJ, Macartney KK, et al. Reduction in rotavirus-associated acute gastroenteritis following introduction of rotavirus vaccine into Australia's National Childhood vaccine schedule. Pediatr Infect Dis J. 2011;30(1 Suppl):S25-9. http://dx.doi.org/10.1097/ INF.obo13e3181fefdee PMid:21183837

11. VIKIA $®$ Rota-Adeno package insert. Marcy l'Etoile: bioMérieux Clinical Diagnostics. [Accessed: 23 May 2013]. Available from: http://www.biomerieuxdiagnostics.com/servlet/srt/bio/clinical-diagnostics/ dynPage?doc=CNL_PRD_CPL_G_PRD_CLN_14

12. Bon F, Kaplon J, Metzger M-H, Pothier P. [Evaluation of seven immunochromatographic assays for the rapid detection of human rotaviruses in fecal specimens]. Path Biol (Paris). 2007;55(3-4):149-53. French. http://dx.doi.org/10.1016/j. patbio.2006.07.044 PMid:17049423 